\title{
Aspects of Applying Distance Education Technologies in the System of University Students Training
}

\author{
Larisa M. Turanova* and Andrey A. Styugin \\ Krasnoyarsk State Pedagogical University \\ named after V.P. Astaf'ev \\ 89 Lebedeva Str., Moscow, 660049, Russia
}

Received 12.11.2014, received in revised form 28.12.2014, accepted 16.01.2015

\begin{abstract}
The processes of informatization of education require considering changes of the informational space of the educational system. Taking into consideration Federal Law "On Education in the Russian Federation", N 11-FZ dated February 28, 2012, Concepts of Development of Research and Innovation Activities in Russian universities, the main benchmark in the field of modernization of educational process should be real integration of education research, developments, introduction of new forms of practice. Universities' efforts on organization of profile distant education of pupils is worth noting. The article describes an approach to implementation of distant learning technologies for creating conditions for modernization of the educational process in the given context.
\end{abstract}

Keywords: E-learning, distance education, innovative practices, integration of education, informatization of education.

Research area: pedagogy.

It should be acknowledged that the informational educational space has changed. Availability of information on the Internet arises a delusion that there is no need to get new knowledge, to learn how to use it. Classical technologies of students' self study using such resources as reports, course papers, lecture notes have transformed into a trivial "copypaste" technology. Distance learning as a global phenomenon of educational and informational culture has been steadily increasing. The industry of distance educational services aimed at new requirements to the educational system (contents of education, communication technologies, informational competences, educational technologies) is developing leaving behind the formation of the concepts of distant learning, rules and regulations in the Russian Federtion and abroad. The demand for distance learning is determined by the increasing demand of any person for having an opportunity to get the high-quality educational services he/she needs any where any time, that would satisfy his/her educational needs. This demand may be satisfied only under the conditions of information transfer, presence of the medium of interactive communication of learners and teachers in the process of education, as well as adaptation of educational technologies to the distance learning conditions. In new informational conditions

(C) Siberian Federal University. All rights reserved

* Corresponding author E-mail address: turanova@yandex.ru 
the tendencies of competencies transformation in the work with information flows should be considered.

This university programme in the area of distance learning development is based on the following prospected changes in the system of education:

1. Forecast development of information technologies

1.1 The rate of information technologies development will remain high providing an opportunity to implement new efficient network technological solutions, technologies of access to the information resources.

1.2 The rate of technology development will remain high giving an opportunity to use new equipment to provide efficient forms of organization of interaction of participants of the educational process, work with different types of information.

1.3 Computer technologies, telecommunication equipment, provision of network technologies will cost less. The cost of complex network decisions will cost more.

2. Forecast changes in the regulative documents about education.

2.1 Distance learning form will be introduced for all levels of education.

2.2 The tendecy for increasing the proportion of self-study for students in educational standards and programmes of higher education will be preserved.

2.3 Requirements to the organization of research and practical work of students will be raised.

3. Forecast tendencies for changes in the role and objectives of the teacher in the conditions of learners' open access to the informational resources of the society

3.1 The function of the teacher as a carrier of subject information will be downplayed
3.2 The function of the teacher as a tutor in the process of organization of teaching will increase, the objectives of teaching how to work with information (mainly, analysis of information, work with meaning, search for information in different information systems) will be strengthened.

3.3 The competent approach in education will gain its priority, the importance of the teacher's competence in applying information technologies (technology aspect) and working with information (content and conceptual aspects) will increase.

In view of the above, the distance learning programme development appear to have the following objectives:

1) Development of the system of learning in Krasnoyarsk State Pedagogical University named after V.P. Astaf'ev for all modes of study basing on implementation of distance learning technologies as:

- a supplement to the classical education system;

- means of organization of students' selfstudy;

- means of supporting classical educational technologies;

- means of optimization of cthe learning process;

- a form of supplementary education.

2) Creation of technological and organizational conditions for developing a united system of distance learning in the region for:

- research and methodological organization of cultural education for pupils in the electronic educational medium to provide equal conditions of access to quality educational services;

- widening the spectrum of educational services provided to the population of the region by the university using distance learning technologies 
To reach the above mentioned objectives, the following programmes are required:

1. To determine development of network and information technologies, development of distance learning technologies as the priority tasks in the development programme of Krasnoyarsk State Pedagogical University named after V.P. Astaf'ev.

2. To form a developed information space of the University, including:

- An opportunity of efficient exchange of information between all structural subdivision of the university (generation of news, an electronic newspaper, an electronic board of advertisements, a schedule, availability of classes etc by all structural subdivisions with the functions of the information management center's modelling)

- Generation of virtual working places for the administration employees and teachers, giving an opportunity:

o to plan educational, research and methodological work,

o to integrate planning and performance of work of all services;

$o$ to regulate management of setting and achieving goals at all levels of the University management;

o to use distance learning technologies for educational activities from any place;

o to organize copmlete elcetronic paper work between all University structures;

- Generation of a consolidated fund of educational resources (educational, methodological, library) for e-reading with protection from illegal reproduction in accordance with the copyright law

3. Development of an authorized system for educational process management with implementation of distance learning technologies, including:

- a unified electronic shell with a corporate access and delineation of powers with implementation of functions of organizational and methodological interaction of participants of the regional educational space and management in the educational system;

- management systems with an access to studied courses in the educational informational medium with elements of automation integrated with the automated Dean's office;

- a control system for self-study of students and course participants of the University supplementary education system;

- a system for education's quality monitoring.

4. Development of the University's electronic services system under the electronic government concepts

5. Development of the technical assistance system for the self-study of a students and teachers' work

- providing wireless access to electronic information space throughout the University, including all academic buildings, dormitories, service buildings.

- allocation of places and equipment for students' self-study using the University's electronic resources (places with stationary computers and places supposing the use of personal equipment by students and teachers)

- equipping classrooms with technologies allowing the teacher to use projection, network and telecommunications equipment without additional service of engineers;

- allocating and equipping isolated working places for teachers (free access 
work places) for teaching materials with video and audio elements to teach classes by means of teleconference with remote students and course participants.

- Consolidation of all network and telecommunication services in the electronic space of the University to organize various types of interaction between all participants of the educational process and research work.

6. Formation of the documents turnover system, including all the necessary information (via personal pages including the information about conferences, publications, various achievements of teachers and students) to generate dynamic reports of different types for different periods.

Therefore, the University structure requires transformations connected with the formation of a unified information center for efficient management of the work with information. Laboratories and centers developing digital resources (electronic books, video, etc) should be united into a unified service for developing educational contents. It would be also important to establish:

- a virtual technology laboratory to study and adapt technological achievements and new forms of technology in the educational process of the University, conducting research on open and distance learning;

- a department of methodological support and expertise of electronic teaching materials to meet the requirements of the distance learning resources developed within the University and outsourcing

- a department of tutor support for educational programmes and individual courses using distance learning technologies
- a department for development of educational Internet projects with students and teachers of the region

The materials of the meeting of the State Council of the Russian Federation on the issues of Russian education modernization [12] include the following objectives as the priority: "state warranty for availability and equal possibilities to get complete education; new up-to-date quality of preschool, general and vocational education; implementation of efficient regulatory and organizational-economic mechanisms of attracting and using resources in the educational system". Federal Law "On Education in the Russian Federation" [2], N 11-FZ [3] dated February 28, 2012, Concepts of Development of Research and Innovation Activities in Russian universities [10] determine real integration of education research, developments, introduction of new forms of practice as the main benchmark in the field of modernization of educational process.

The following measures should be taken as a prerequisite for achieving the new quality of higher education [12]: "forecasting the needs of the labour market and development of cooperation network of professional educational institutions, recruitment and information agencies, employment services; adjusting vocational education to the needs of territories and regional labour markets".

During his analysis of the influence of innovative development mechanisms on the institute of education, B.V. Sazonov has identified the following requirements, which determine the innovative approach [13]:

- following the dynamics of the "growing" needs of the consumer of services, direct involvement in the formation of new needs of the consumer;

- organization and development of research as the service to generate new funds for meeting new needs of the consumer. 
Thus, the vector of Russian universities' development as part of the modernization of the education system is defined as the introduction of new forms of practice; organization of profile distance learning for pupils. For pedagogical universities, an important component of cooperation with educational institutions, first of all, the regional ones, is joint search for new approaches and pedagogical techniques for the different stages of the educational system given the current level of information technologies development.

The strategic goal of Krasnoyarsk State Pedagogical University until 2020 is "to meet the demandsofthesocietyoftheKrasnoyarsk Territory and other regions of Siberia regarding modern qualitative education in the field of pedagogy, sociology and the humanities to increase the human assets, life quality and development of the Krasnoyarsk Territory and other Siberian regions" $[14$, P. 3]. This is connected with the development of "demanded professional and socially important personal competences of the University students, their personal identity in life and readiness for innovative and creative professional activities and modernization of Russian society" [14, P. 4]. In the thesis research [11], A.V. Maister provides the following determination: "Innovative pedagogical experience is a complex of creative active learning and implementation of knowledge and skills with the elements of novelty and discoveries introduced by the subjects of the regional educational system aimed at its successful modernization given corresponding research, project and management components".

In the view of the above, we consider it important to involve students into activities that allow to form professional experience during different types of practices and research work. For a pedagogical university it is important to involve students into activities that give an opportunity to gain innovative pedagogical experience working in educational institutions of different types with implementation of modern technologies.

The Distance Learning Center of Krasnoyarsk State Pedagogical University integrates the subjects of the educational process of the University, the University resource centers in the Krasnoyarsk Territory, several departments of education and educational institutions of the Krasnoyarsk Territory in the field of distance learning. Under distance learning we employ the organization of cognitive activities with such pedagogical support, when pedagogical communication is as minimum as possible [16, P. 305]. Teachers of the Krasnoyarsk Territory participate in the "Virtual Classroom" project (the authors of the project are L.M. Turanova, A.A. Stiugin), which is implemented on the technology basis of the University by cluster technology. For students the "Virtual Classroom" project is an opportunity to try their research work in the field of individual methods with the use of distance learning technologies, to implement their project ideas in organization research, pedagogical and cultural work with pupils using distance learning technologies. The "Virtual Classroom" project has given positive results in the experiment on organization of innovative pedagogical practice. Students gain very rewarding experience in such kind of activities. It is not only the specifics of remote organization of educational activities that they learn about; they also get to know the specifics of educational institutions in remote areas of the Krasnoyarsk Territory.

The demand for distance learning in the system of professionally oriented work with pupils is determined by several factors [15, P. 7]: modern information technologies cause an increased interest among pupils; secondary educational institutions, especially small schools have difficulty in providing variability of elective courses; participation of universities in 
professionally oriented work with pupils without distance learning system can not provide equal conditions for pupils from schools in remote areas. We consider it important to involve students of different universities into organization of professionally oriented work with pupils in the fields of their future professional activities.

We consider it important to involve students of different universities into educational activities with pupils, it is especially important for the students of pedagogical universities. Taking into account that "pedagogical work should be not a separate element of extra-curricular pedagogical work, but a required component of pedagogical work integrated into the general process of education and development" [12]. It is up to date to involve students into pedagogical projects with implementation of distance learning technologies.

Students participate in generation of new forms of cooperation by joining the cooperative activities of the University with educational institutions of the Krasnoyarsk Territory within the framework of "Days of Krasnoyarsk State Pedagogical University", participating in exhibitions, concerts and round-table discussion involving pupils, students and educational workers where topical problems of education were discussed: joint scientific and methodological conferences, lectures, museum programmes etc. Therefore, pedagogical training widens the possibilities of forming social and personal competences of University students, their life identity and readiness for innovative creative professional activities.

Taking into consideration that "school in the broader meaning of the word should become the most important factor of humanization of social and economic relations, formation of new life settings of a person", oriented at the active position and decision-making in the conditions of uncertainty, able for cooperation, intercultural cooperation and development of new social approaches and practices [12], the Distance Learning Center of Krasnoyarsk State University actively works with students in terms of searching for innovative forms of cooperation with educational institutions of the Krasnoyarsk Territory, with implementation of distance learning technologies. A student project "Organization of the System of Psychological and Pedagogical Consulting of Parents and Professional Support for Teachers of Taimyr, Dolgano-Nenetsk Municipal District Using Distance Learning Technologies" (supervisor A.A. Stiugin) implemented with the scientific ad methodological support of the department of distance education became the prize winner of the competition of student projects under the order of the municipal institutions held by the Krasnoyarsk Regional Fund of Support of Research and Technological Activities. The following student projects participate in the competition: "Development of the Virtual Museum Medium for Storage and Study of History of the Peoples of Taimyr Dolgano-Nenetsk Municipal District for Support of Ethno-Cultural Objects As a National and Regional Component of Basic Education"; "Children and Youth Recruitment Art Agency as a Prerequisite for Development of the System of Supplementary Education in Bogotol Town",

Therefore, in our opinion involvement of students into different kinds of future professional activities with implementation of distance learning technologies meets the requirements of modern education, trends of humanization of social and economic relations, and contributes to the formation of new life settings of the student's personality oriented at the active position and decision making in the conditions of uncertainty, able for cooperation, intercultural cooperation and development of new social approaches and practices, formation of innovative pedagogical experience. 


\section{References}

1. Bukharov A.V., Zinov V.G., Kirko V.I. Ob universitetskoi structure universitetskikh kompleksov [About University Structure of the University Complexes] // Innovations. 2008. No. 7. P.3 8-43.

2. Federal Law "About Education of the Russian Federation" [Online Resource] Available at :http://base.consultant.ru/cons/cgi/online.cgi?req=doc;base=LAW;n=132509;dst=4294967295;rnd=0.2 4894562540813614;from=121836-0

3. Federal Law N 11-FZ dated February 28, 2012 [Online Resource] Available at: http://base. consultant.ru/cons/cgi/online.cgi?req=doc;base=LAW;n=126574

4. Karlova O.A., Koptseva N.P., Kirko V.I., Reznikova K.V., Zamaraeva Iu.S., Sertakova E.A., Kistova A.V. Shishatsky N.G., Viktoruk E.A., Viktoruk E.N. et al. Novoe budushchee Sibiri: ozhidaniia, vyzovy, resheniia [New Future of Siberia: Expectations, Challenges and Decisions], Krasnoyarsk, 2013.

5. Kirko V.I., Pack N.I., Malakhova E.V. Education for the Future: New Strategies of Distance Education for the Universities of Eastern Siberia // Turkish Online Journal of Distance Education. 2014. V.15 (1): 23-32.

6. Koptseva N.P., Kirko V.I. Specificity of Ethnogeny Indigenous Peoples of Central Siberia in the Transition from the Traditional Type of Society to Modern Society. Life Sci J 2014;11(7):409-413.

7. Koptseva N.P., Kirko V.I.. Modern Specificity of Legal Regulation of Cultural Development of the Indigenous Peoples of the Arctic Siberia under the Global Transformations. Life Sci J 2014;11(9):314-319.

8. Koptseva N.P., Kirko V.I. Post-Soviet Practice of Preserving Ethnocultural Identity of Indigenous Peoples of the North and Siberia in Krasnoyarsk Region of the Russian Federation. Life Sci J 2014;11(7):180-185.

9. Koptseva N.P., Kirko V.I. The Information Basis for Formation of Positive Ethnic Identities in the Process of Acculturation of Indigenous Peoples of the Arctic Siberia (Krasnoyarsk, Russia). Life Sci J 2014;11(8):479-483.

10. Konseptsiia razvitiia issledovatel'skoi $i$ innovatsionnoi deiattel'nosti v rossiiskikh vuzakh [Concepts of Development of Research and Innovative Activities in Russian Universities] [Online Resource] Available at: http://base.consultant.ru/cons/cgi/online. cgi?req=doc;base=EXP; $=506134$

11. Maister A.V. Innovatsionny pedagogicheskii opyt kak factor modernizatsii regional'noi sistemy obrazovaniia [Innovative Pedagogical Experience As a Factor of Modernization of the Regional Educational System] /author's abstract of the thesis/ Cheliabinsk, 2009. [Online Resource] Available at: http://www.ceninauku.ru/info/page_11775.htm

12. Modrnizatsiia rossiiskogo obrazovaniia: dokumenty $i$ materialy [Modernization of Russian Education: Documents and Materials] / Editor E.D. Dneprov/ State Institution Higher School of Economics, Moscow: 2002. 332 p. [Online resource] Available at: http://ecsocman.hse.ru/ data/497/700/1219/5.pdf

13. Sazonov B.V. Problemy i puti modernizatsii rossiiskogo obrazovaniia [Problems and Ways of Modernization of Russian Education]/Nekommercheskii nauchnyi Fond "Institut razvitiia im. G.P. Shchedrovitskogo [Non-commercial Research Foundation "Institute of Development named after G.P. Schedrovitsky] [Online Resource] Available at: http://www.fondgp.ru/lib/mmk/49/\#_ftnref4

$$
-474-
$$


14. Strategicheskaia tsel' razvitiia KGPU im. V.P. Astaf'eva do 2020 goda: videnie, missiia, prioritety $i$ tselevye zadachi [Strategic Goal of Development of Krasnoyarsk State Pedagogical University named after V.P. Astaf'ev until 2020: Vision, Mission, Priorities and Target Objectives] [Online Resource] Available at: http://www.kspu.ru/upload/documents/old/str_1316655068.pdf

15. Stiugin A.A., Turanova L.M. Organizatsiia distantsionnykh elektivnykh kursov v sisteme proforientatsionnoi raboty pedagogicheskogo vuza: metodicheski rekomendatsii [Organization of Distance Electronic Courses in the System of Professionally Oriented Work of the Pedagogical University: Methodological Recommendations]/ Krasnoyarsk State Pedagogical University named after V.P. Astaf'ev. Krasnoyarsk, 2010. 40 p.

16. L.M. Turanova, A.A. Stiugin, N.O. Turanov. Organization of Higher Professional Education Using Distance Technologies at the V.P. Astafev Krasnoyarsk State Pedagogical University / Intercultural Ties in Higher Education and Academic Teaching, Israel, September 19-21. Israel, 2011, P. 305-314.

\title{
Аспекты применения дистанционных технологий в системе подготовки студентов университета
}

\author{
Л.М. Туранова, А.А. Стюгин \\ Красноярский государственный педагогический университет \\ им. В.П. Астафьева \\ Россия, 660049, Красноярск, ул. Лебедевой, 89
}

\begin{abstract}
Процессы информатизации образования требуют учета изменений информационного пространства системы обучения. Принимая во внимание Ф3 «Об образовании в Российской Федерации», Ф3 РФ от 28.02.12 2. № 11-Ф3, Концеепџию развития исследовательской и инновачионной деятельности в российских вузах, основным ориентиром в области модернизачии образовательного процесса должна стать реальная интеграция образования, исследований, разработок, внедрения; потребуется внедрение новых форм практики; заслуживает внимания работа вузов по организации профильного дистаничонного обучения школьников. В статье приводится видение применения дистанционных образовательных технологий с иелью создания условий для модернизации образовательного процесса в указанном контексте.
\end{abstract}

Ключевые слова: дистанционные образовательные технологии, инновачионная практика, интеграция образования, информатизаиия образования.

Научная специальность: 13.00.00 - педагогические науки. 